\title{
Intravenous administration of the conditionally replicative adenovirus Ad5- $\triangle$ 24RGD induces regression of osteosarcoma lung metastases
}

\author{
Harm CA Graat*1, Victor W van Beusechem², Frederik HE Schagen ${ }^{2}, \mathrm{M}$ \\ Adhiambo Witlox ${ }^{1}$, Eugenie S Kleinerman ${ }^{3,4}$, Marco N Helder ${ }^{1}$, \\ Winald R Gerritsen ${ }^{2}$, Gertjan JL Kaspers ${ }^{5}$ and Paul IJM Wuisman ${ }^{1}$
}

Address: ${ }^{1}$ Department of Orthopedic Surgery, VU University medical center, De Boelelaan 1117, 1081 HV, Amsterdam, the Netherlands, ${ }^{2}$ Department of Medical Oncology, VU University medical center, De Boelelaan 1117, $1081 \mathrm{HV}$, Amsterdam, the Netherlands, ${ }^{3}$ Division of Pediatrics, University of Texas, M. D. Anderson Cancer Center, 1515 Holcombe Blvd, Houston, TX 77030, USA, ${ }^{4}$ Department of Cancer Biology, University of Texas, M. D. Anderson Cancer Center, 1515 Holcombe Blvd, Houston, TX 77030, USA and ${ }^{5}$ Department of Pediatric Oncology/ Hematology, VU University medical center, De Boelelaan 1117, 1081 HV, Amsterdam, the Netherlands

Email: Harm CA Graat* - hca.graat@vumc.nl; Victor W van Beusechem - vw.vanbeusechem@vumc.nl; Frederik HE Schagen - e.schagen@vumc.nl; M Adhiambo Witlox - ma.witlox@vumc.nl; Eugenie S Kleinerman - ekleiner@mdanderson.org; Marco N Helder - m.helder@vumc.nl; Winald R Gerritsen - winald.gerritsen@vumc.nl; Gertjan JL Kaspers - gjl.kaspers@vumc.nl; Paul IJM Wuisman - orthop@vumc.nl

* Corresponding author

Published: 23 January 2008

Molecular Cancer 2008, 7:9 doi:10.1186/1476-4598-7-9
Received: 16 August 2007

Accepted: 23 January 2008

This article is available from: http://www.molecular-cancer.com/content/7/I/9

(C) 2008 Graat et al; licensee BioMed Central Ltd.

This is an Open Access article distributed under the terms of the Creative Commons Attribution License (http://creativecommons.org/licenses/by/2.0), which permits unrestricted use, distribution, and reproduction in any medium, provided the original work is properly cited.

\begin{abstract}
Metastatic osteosarcoma (OS) has a very poor prognosis. New treatments are therefore wanted. The conditionally replicative adenovirus Ad5- 2 24RGD has shown promising anti-tumor effects on local cancers, including OS. The purpose of this study was to determine whether intravenous administration of Ad5- 2 24RGD could suppress growth of human OS lung metastases. Mice bearing $\mathrm{SaOs}-\mathrm{Im} 7$ OS lung metastases were treated with Ad5- 2 24RGD at weeks I, 2 and 3 or weeks 5, 6 and 7 after tumor cell injection. Virus treatment at weeks I-3 did not cause a statistically significant effect on lung weight and total body weight. However, the number of macroscopic lung tumor nodules was reduced from a median of $>158$ in PBS-treated control mice to 58 in Ad5- 24 RGDtreated mice $(P=0.15)$. Moreover, mice treated at weeks $5-7$ showed a significantly reduced lung weight (decrease of tumor mass, $p<0.05$ ), a significantly increased body weight gain (decrease of disease symptoms, $P<0.005$ ) and a reduced number of macroscopic lung tumor nodules (median 60 versus $>149, p=0.12$ ) compared to PBS treated control animals. Adenovirus hexon expression was detected in lung tumor nodules at sacrifice three weeks after the last intravenous adenovirus administration, suggesting ongoing viral infection. These findings suggest that systemic administration of Ad5- $\triangle 24 R G D$ might be a promising new treatment strategy for metastatic osteosarcoma.
\end{abstract}




\section{Findings}

Osteosarcoma is the most prevalent non-hematological primary malignant bone tumor. They can be subdivided by location (medullary and surface) and by grade (high or low grade). The vast majority of high-grade osteosarcoma comprises of conventional osteosarcoma, but also includes high-grade surface, telangiectatic and small-cell osteosarcoma [1]. Patients with high-grade osteosarcoma (OS) without evident metastatic disease at presentation have 5-year survival of about 50-70\% achieved by preoperative and postoperative chemotherapy with aggressive surgery [2-6]. Patients presenting with overt metastatic disease undergo the same pre- and postoperative chemotherapeutic regimen with resection of all metastases whenever feasible. The majority of osteosarcoma metastases are located in the lungs $[4,7,8]$. Multiple lung metastases and bilateral distribution appear to be poor prognostic factors for survival with 5 -year overall survival rates of $26 \%$ and $20 \%$, respectively; in contrast to $75 \%$ for a solitary lung lesion [8]. Moreover, OS patients that relapse after first achieving complete surgical remission during combined-modality chemotherapy have a 5-year overall survival of $23 \%$ [9]. Long-term survivors were only observed after a second surgical remission, indicating that metastastectomy of all lesions is essential. The role of second-line chemotherapeutic agents is unsure and might result in limited improved outcome [9]. Clearly, for inoperable OS patients new treatment modalities are needed.

We explore the use of conditionally replicative adenoviruses (CRAds) as a potential new treatment modality for high grade OS and its lung metastases. Virus replication will lyse tumor cells and released viral progeny can infect neighboring tumor cells leading to lateral spread and increased tumor cell kill. Previously we found that primary OS cells express low levels of the high affinity receptor for adenoviruses, the coxsackie and adenovirus receptor (CAR) $[10,11]$. In contrast, primary OS cells express high levels of integrins [12]. To circumvent CAR deficiency and thereby reduced tumor cell infectivity, we use the CRAd variant Ad5- 2 24RGD that carries a cyclic Arg-Gly-Asp (RGD-4C) integrin binding motif in its fiber knob domain [13]. This CRAd expresses mutant E1A that cannot bind to pRb. Consequently, E2F, essential for viral replication, is not released. Therefore, this CRAd is limited to replicate in cancer cells with constitutively active E2F and not in non-cycling normal cells with functional $\mathrm{pRb}$ [14]. In vivo experiments showed that this virus induced tumor regression of subcutaneous glioma, osteosarcoma and cervical cancer tumors after intra-tumoral or systemic administration [12,15-17]. Infection of CAR-deficient OS cells with this integrin-targeted virus resulted in increased infectivity and cell kill. Furthermore, we showed that intra-tumoral administration of Ad5- 224 RGD in subcuta- neous primary OS tumors resulted in a significant tumor growth delay [12].

Local treatment of OS with CRAds has shown promising results in animal models $[12,18]$. However, the major challenge to cure OS patients depends on an effective treatment for (non-resectable) metastases. Biodistribution studies in animals indicated that a considerable amount of intravenously administered Ad5- $\Delta 24$ RGD is delivered to the lungs (25\% of the liver dose) [17]. In addition, the RGD-modification might partially avoid reduced infectivity as result of neutralizing antibodies $[19,20]$. In the present study, we explore the use of intravenous administered Ad5- $\triangle 24 \mathrm{RGD}$ for the treatment of OS lung metastases.

We first performed a pilot study in which mice were given $1 \times 10^{9}$ plaque forming units ( $\mathrm{pfu}$ ) intravenously once a week for three consecutive weeks $\left(3 \times 10^{9} \mathrm{pfu}\right.$ total $)$. This was the practically highest achievable dose and injection of this amount of virus did not affect body weight, suggesting that it did not induce overt toxicity. Therefore, this dose was chosen to explore the anticancer potency against OS lung metastases. SaOs-lm7 cells were injected intravenously into mice to establish OS lung metastases [21]. In a first experiment, mice bearing OS lung metastases were treated with $1 \times 10^{9} \mathrm{pfu}$ Ad5- 24 RGD or with PBS at weeks 1, 2 and 3 after SaOs-lm7 injection. As parameter of mouse well-being, their relative gain in body weight was calculated. Ten weeks after tumor cell injection, mice were sacrificed and their lungs dissected. Mouse lung weight and number of macroscopic lung tumor nodules were quantified to assess Ad5- $\Delta 24 \mathrm{RGD}$ anticancer effect. Mice treated with Ad5- $\Delta 24$ RGD or PBS showed no significant difference in body weight gain during the experiment (data not shown). As shown in figure 1a, average lung weight of virus treated animals appeared to be decreased in comparison to PBS treated control animals, but this difference was statistically not significant $(p=0.15)$. Macroscopic appearance of the lungs reflected the lung weight measurements, where a lower lung weight paralleled fewer and smaller lung metastases and a higher lung weight correlated with more and larger lung metastases (figures 1b). In the PBS treated group, lungs often contained numerous lung metastases; sometimes more than could be counted ( $>200$ ). The median number of macroscopic tumor nodules on the lungs of PBS treated animals was >158 (range $24->200$ ). Lungs of Ad5- $\Delta 24$ RGD treated animals carried a median number of 58 lung metastases (range 26-155; figure 1c).

In a next experiment, we delayed the onset of oncolytic adenovirus treatment by 4 weeks. Virus or PBS was injected once per week at 5, 6 and 7 weeks after SaOs-lm7 tumor cell injection. Mice treated with Ad5- $\Delta 24$ RGD 
a

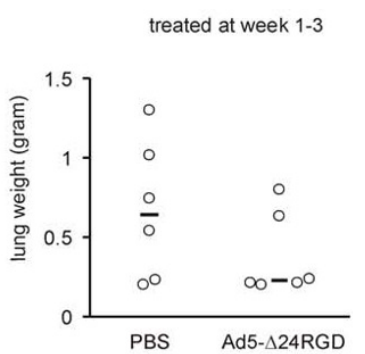

b PBS

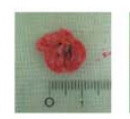

treated at week $1-3$
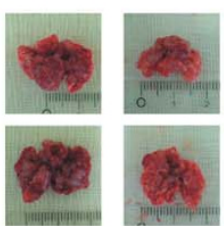

Ad5- $\triangle 24 R G D$
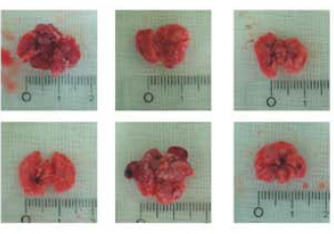

Ad5- $\triangle 24 R G D$
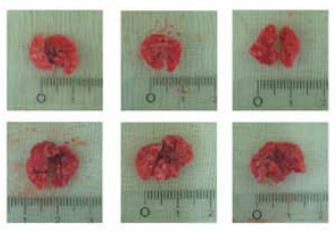

C

\begin{tabular}{|c|c|c|c|}
\hline Treatment & $\begin{array}{l}\text { Treatment } \\
\text { weeks }\end{array}$ & $\begin{array}{l}\text { Number of tumor nodules } \\
\text { (6 mice in each group) }\end{array}$ & median \\
\hline PBS & $1-3$ & $24 ; 44 ; 116 ;>200 ;>200 ;>200$ & $>158$ \\
\hline $\begin{array}{c}\text { Ad5- } \\
\Delta 24 R G D\end{array}$ & $1-3$ & $26 ; 32 ; 50 ; 66 ; 72 ; 155$ & 58 \\
\hline PBS & $5-7$ & $4 ; 85 ; 98 ;>200 ;>200 ;>200$ & $>149$ \\
\hline $\begin{array}{c}\text { Ad5- } \\
\Delta 24 R G D\end{array}$ & $5-7$ & $0 ; 1 ; 15 ; 104 ; 160 ; 172$ & 60 \\
\hline
\end{tabular}

d
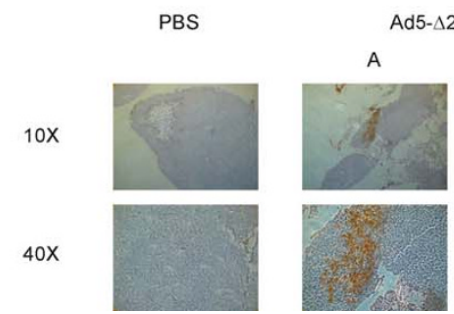

Ad5- $\triangle 24 R G D$
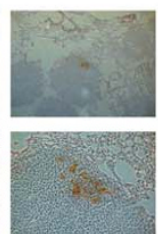

\section{Figure I}

Therapeutic effect of Ad5- 2 24RGD infusion I-3 (left panel figure a \& b) or 5-7 (right panel figure a \& b) weeks after SaOs-Im7 injection. (a) Effect of intravenous administration of Ad5- 24 RGD on OS pulmonary tumor burden. Lungs were removed and weighed. Open circles depict lung weight of each mouse and black lines show the median of each group. (b) Macroscopic appearance of dissected lungs. (c) Number of lung tumor nodules per mouse. (d) Immunohistochemical staining for expression of the adenovirus hexon protein in lungs of mice treated at weeks 5-7. Ten weeks after tumor cell injection and three weeks after the last virus injection lungs were isolated and analyzed for hexon expression. Representative pictures of the lungs from a PBS control mouse and two Ad5- $\triangle 24 R G D$ treated mice (A \& B) are shown at 10× and 40× magnification. 
showed an average increase in weight of $18 \%$, which was significantly higher than the average $8 \%$ weight gain observed for PBS treated control animals $(\mathrm{P}<0.005)$. Moreover, intravenous administration of Ad5- $\Delta 24$ RGD resulted in a significant reduction of lung weight (median $241 \mathrm{mg})$ compared to PBS treated control animals (median $723 \mathrm{mg}$; figure 1a; $\mathrm{P}<0.05$ ). The lung weight of virus treated mice was just above normal mouse lung weight (i.e., approximately $180 \mathrm{mg}$ ). The higher tumor mass in the PBS treated group suggested that the total body weight gain, after correction for increased tumor mass, differed even more between the PBS and virus treated animals. Also in this experiment, macroscopic appearance reflected lung weight measurements (figure $1 \mathrm{~b})$. The median number of macroscopic lung metastases (figure 1c) in PBS treated animals was $>149$ (range 4 $>200$ ) and in Ad5- $\Delta 24$ RGD treated animals 60 (range 0 172).

To strengthen the hypothesis that intravenous delivered Ad5- -24 RGD caused an antitumor effect against OS lung metastases, the lungs of mice from the second experiment treated with Ad5- $\Delta 24 \mathrm{RGD}$ at weeks 5-7 and dissected at week 10 were analyzed for adenoviral infection by hexon staining. As shown in figure $1 \mathrm{~d}$, foci of infected cells were present in SaOs-lm7 lung nodules, but not in normal lung tissue. Thus, adenovirus infection could still be detected in OS lung metastases 3 weeks after the last intravenous Ad5- $\Delta 24$ RGD injection, supporting the assumption that ongoing virus infection contributed to the beneficial effects of systemic CRAd treatment. Adenovirus-positive foci were not surrounded by apparent fibrosis, suggesting that connective tissue barriers did not hamper intra-tumor spread of the virus. However, such efficacy-limiting physical barriers might exist in OS.

In general, Ad5- $\Delta 24 \mathrm{RGD}$ treatment seemed to reduce lung weight and number of macroscopic tumor nodules in both tested treatment schedules. These parameters are commonly used for therapeutic efficacy evaluation. Treatment effects were most evident when virus treatment was applied 5-7 weeks after tumor cell injection. Treatment at week 5-7 also resulted in a significant body weight increase, suggesting improved mouse well-being. More insight into the kinetics of OS lung metastasis growth and response to treatment could be obtained if longitudinal in vivo imaging of SaOs-lm7 tumor growth would be possible. Unfortunately, a derivative reporter cell line for bioluminescent imaging is not available.

Together, our observations suggest that Ad5- $\Delta 24 \mathrm{RGD}$ is active against OS lung metastases, which is in line with recent finding by Li et al [22], who showed that a transcriptional replication-competent adenovirus (AdOCE1a) reduced the number of OS lung tumor nodules. Fur- thermore, our experiments suggest that timing of virus injection influences treatment outcome. A possible explanation for the more effective outcome in mice treated at weeks 5-7 might be found in a dependence on an established tumor vasculature for systemic CRAd delivery. SaOs-lm7 injected tumor cells will form microscopic lung metastases by 3-5 weeks and visible lung nodules by 6 weeks [21]. Microscopic tumors are usually in a pre-vascular state and only growth beyond $2-3 \mathrm{~mm}^{3}$ requires blood vessel formation [23]. Virus injected at week 1-3 thus presumably treats isolated tumor cells or microscopic tumor nodules, which could be reached via diffusion, whereas treatment at week 5-7 would allow vascular delivery to macroscopic tumor nodules. Although we documented significant therapeutic efficacy after three injections of Ad5- $\Delta 24 \mathrm{RGD}$, mice were not completely cured from their OS lung metastases. To increase treatment efficacy extended administration schemes could be tested. In addition, in a clinical setting in humans isolated lung perfusion to increase CRAd delivery could be considered. Several clinical trials delivering therapeutic agents to sarcoma lung metastases via isolated lung perfusion have been conducted [24]. Clinical trials with Ad5- $\Delta 24$ RGD for the treatment of glioma and ovarian cancer are developed and will be started soon [25]. These studies will provide valuable data on the safety profile of this CRAd in humans important to pursue development of Ad5- $\triangle 24 \mathrm{RGD}$ for OS and OS lung metastases treatment.

\section{Methods \\ Cell lines}

SaOs-lm7 cells are derived from SaOs- 2 human OS cells by repetitive cycling through the lungs of nude mice [21]. SaOs- $\operatorname{lm} 7$ cells are grown in Eagle's minimal essential medium supplemented with nonessential amino acids, sodium pyruvate, L-glutamine, $10 \%$ fetal calf serum (FCS) and $50 \mathrm{IU} / \mathrm{ml}$ penicillin plus $50 \mu \mathrm{g} / \mathrm{ml}$ streptomycin (PS; Life Technologies, Breda, the Netherlands). Cultures are maintained and harvested at sub-confluence. A549 and 293 cells were obtained from the American Type Culture Collection (Manassas, VA) and are maintained in F12supplemented Dulbecco's modified Eagle's medium (DMEM) with 10\% FCS and PS. All cells are cultured at $37^{\circ} \mathrm{C}$ in a humidified, $5 \%$ carbon dioxide atmosphere.

\section{Recombinant adenoviruses}

The CRAd Ad5- $\triangle 24$ RGD lacks 24 base pairs encoding 8 amino acids in the pRb binding domain of E1A and carries a cyclic RGD epitope in the HI-loop of the fiber [13]. This CRAd was propagated on A549 cells. Virus was purified using cesium chloride gradient banding. Functional titers in pfu were determined by end-point limiting dilution on 293 cells. 


\section{OS lung metastasis model in nude mice}

Female athymic/nude/nude mice were purchased from Harlan (Horst, the Netherlands). Animals were maintained under pathogen-free conditions and fed a standard laboratory diet ad libitum. All experiments were approved by the local committee on animal experiments and were carried out under the conditions established by the European Community (directive 86/609/CCE). Mice were injected with $5 \times 10^{6} \mathrm{SaOs}-\operatorname{lm} 7$ cells in the lateral tail vein in $200 \mu \mathrm{l}$ Hanks Balanced Salt Solution w/o calcium and magnesium. Intravenous injection of $\mathrm{SaOs}-\operatorname{lm} 7$ cells results in microscopic lung metastases by week 3-5 and macroscopic disease at 6 weeks.

\section{Intravenous administration of Ad5- $224 R$ GD to mice bearing osteosarcoma lung metastases}

In two independent experiments, 12 mice bearing SaOs$\operatorname{lm} 7$ lung metastases were randomly divided into 2 groups of each 6 mice. Mice were treated three times, in weeks 1 , 2 , and 3 (experiment 1 ) or in weeks 5, 6 and 7 (experiment 2). The first group received intravenous injections in the tail vein of $1 \times 10^{9} \mathrm{pfu}$ Ad5- $\Delta 24 \mathrm{RGD}$ in $200 \mu \mathrm{l}$ PBS and the second control group received $200 \mu \mathrm{l}$ PBS.

Body weight was measured twice a week. All mice were sacrificed in week 10 after tumor cell injection. The lungs were removed in toto without difficulty and photographed. Two researchers counted tumor nodules on the outside of the lungs independently and the average of the two measurements was calculated. Lungs were snap frozen in liquid nitrogen and weighed using a Mettler H31 ( \pm $0.1 \mathrm{mg}$; Mettler-Toledo International Inc).

\section{Immunohistochemical analysis}

Cryosections of lungs obtained at week 10 from mice treated at weeks 5, 6 and 7 after tumor cell injection were fixed in acetone. Immunohistochemical staining for adenovirus (hexon) was done using goat anti-adenovirus antibody 1056 (Chemicon International, Temecula, CA). Sections were then incubated with biotinylated goat antirabbit IgG antibodies. The immune reaction was visualized using the streptavidin-biotin-Horse Radish peroxidase complex method (StrepABComplex/HRP; Dako, Glostrup, Denmark) followed by diaminobenzidine solution (Vector Laboratories, Inc., Burlingame, CA). Sections were counterstained with hematoxylin (Sigma Aldrich, St. Louis, MO), dehydrated and mounted.

\section{Statistical analysis}

Differences in relative gain in mouse weight, number of lung metastases and total lung weight between treatment groups were analyzed with a two and one-tailed MannWhitney test, respectively, using GraphPad Instat 3.0 (GraphPad Software, Inc., San Diego, CA).

\section{Competing interests}

The author(s) declare they have no competing interests.

\section{Authors' contributions}

HCAG: designed and carried out the experiments and drafted the manuscript

VWB: designed experiments, analyzed data and critically commented on final manuscript

FHES: counted OS lung tumor metastases and corrected manuscript

MAW: optimized mouse model and corrected manuscript

ESK: optimization of mouse model, and commented on manuscript

MNH: designed experiments and corrected manuscript

WRG: supervised project and commented on manuscript

GJLK: obtained funding, supervised project and corrected final manuscript

PIJMW: obtained funding, supervised project and corrected final manucript

All authors read and approved the final manuscript.

\section{Acknowledgements}

In memory of professor Paul I.J.M. Wuisman.

\section{References}

I. Fletcher CDM, Unni KK, Mertens F: WHO Classification of tumours. Pathology and Genetics of Tumours of Soft Tissue and Bone. Lyon, IARC Press; 2002.

2. Bielack SS, Kempf-Bielack B, Delling G, Exner GU, Flege S, Helmke K, Kotz R, Salzer-Kuntschik M, Werner M, Winkelmann W, Zoubek A Jurgens $\mathrm{H}$, Winkler K: Prognostic factors in high-grade osteosarcoma of the extremities or trunk: an analysis of I,702 patients treated on neoadjuvant cooperative osteosarcoma study group protocols. J Clin Oncol 2002, 20:776-790.

3. Goorin AM, Schwartzentruber DJ, Devidas M, Gebhardt MC, Ayala AG, Harris MB, Helman LJ, Grier HE, Link MP: Presurgical chemotherapy compared with immediate surgery and adjuvant chemotherapy for nonmetastatic osteosarcoma: Pediatric Oncology Group Study POG-865I. J Clin Oncol 2003, 2I:1574-1580.

4. Bacci G, Ferrari S, Longhi A, Perin S, Forni C, Fabbri N, Salduca N, Versari M, Smith KV: Pattern of relapse in patients with osteosarcoma of the extremities treated with neoadjuvant chemotherapy. Eur J Cancer 200I, 37:32-38.

5. Lewis IJ, Nooij MA, Whelan J, Sydes MR, Grimer R, Hogendoorn PC, Memon MA, Weeden S, Uscinska BM, van Glabbeke M, Kirkpatrick A, Hauben El, Craft AW, Taminiau AH: Improvement in histologic response but not survival in osteosarcoma patients treated with intensified chemotherapy: a randomized phase III trial of the European Osteosarcoma Intergroup. J Natl Cancer Inst 2007, 99: II2-128.

6. Eselgrim M, Grunert H, Kuhne T, Zoubek A, Kevric M, Burger H, Jurgens $\mathrm{H}$, Mayer-Steinacker R, Gosheger G, Bielack SS: Dose intensity of chemotherapy for osteosarcoma and outcome in the 
Cooperative Osteosarcoma Study Group (COSS) trials. Pediatr Blood Cancer 2006, 47:42-50.

7. Voute PA, Souhami RL, Nooij M, Somers R, Cortes-Funes H, van der Eijken JW, Pringle J, Hogendoorn PC, Kirkpatrick A, Uscinska BM, van Glabbeke M, Machin D, Weeden S: A phase II study of cisplatin, ifosfamide and doxorubicin in operable primary, axial skeletal and metastatic osteosarcoma. European Osteosarcoma Intergroup (EOI). Ann Oncol 1999, 10:1211-1218.

8. Kager L, Zoubek A, Potschger U, Kastner U, Flege S, Kempf-Bielack $B$, Branscheid D, Kotz R, Salzer-Kuntschik M, Winkelmann W, Jundt G, Kabisch H, Reichardt P, Jurgens H, Gadner H, Bielack SS: Primary metastatic osteosarcoma: presentation and outcome of patients treated on neoadjuvant Cooperative Osteosarcoma Study Group protocols. J Clin Oncol 2003, $21: 201$ I-20 I8.

9. Kempf-Bielack B, Bielack SS, Jurgens $H$, Branscheid D, Berdel WE, Exner GU, Gobel U, Helmke K, Jundt G, Kabisch H, Kevric M, Klingebiel T, Kotz R, Maas R, Schwarz R, Semik M, Treuner J, Zoubek A, Winkler K: Osteosarcoma relapse after combined modality therapy: an analysis of unselected patients in the Cooperative Osteosarcoma Study Group (COSS). J Clin Oncol 2005, 23:559-568.

10. Witlox MA, Van Beusechem VW, Grill J, Haisma HJ, Schaap G, Bras J, Van Diest P, De Gast A, Curiel DT, Pinedo HM, Gerritsen WR, Wuisman PI: Epidermal growth factor receptor targeting enhances adenoviral vector based suicide gene therapy of osteosarcoma. J Gene Med 2002, 4:5। 0-516.

II. Graat HC, Wuisman PI, van Beusechem VW, Carette JE, Gerritsen WR, Bras J, Schaap GR, Kaspers G], Ogose A, Gu W, Kawashima H, Hotta $T$ : Coxsackievirus and adenovirus receptor expression on primary osteosarcoma specimens and implications for gene therapy with recombinant adenoviruses. Clin Cancer Res 2005, I I:2445-7; author reply 2447-8.

12. Witlox AM, Van Beusechem VW, Molenaar B, Bras H, Schaap GR, Alemany R, Curiel DT, Pinedo HM, Wuisman PI, Gerritsen WR: Conditionally replicative adenovirus with tropism expanded towards integrins inhibits osteosarcoma tumor growth in vitro and in vivo. Clin Cancer Res 2004, 10:6I-67.

13. Suzuki K, Fueyo J, Krasnykh V, Reynolds PN, Curiel DT, Alemany R: A conditionally replicative adenovirus with enhanced infectivity shows improved oncolytic potency. Clin Cancer Res 200I, 7:120-126.

14. Fueyo J, Gomez-Manzano C, Alemany R, Lee PS, McDonnell T], Mitlianga P, Shi YX, Levin VA, Yung WK, Kyritsis AP: A mutant oncolytic adenovirus targeting the Rb pathway produces antiglioma effect in vivo. Oncogene 2000, 19:2-12.

15. Lamfers ML, Grill J, Dirven CM, Van Beusechem VW, Geoerger B, Van Den Berg J, Alemany R, Fueyo J, Curiel DT, Vassal G, Pinedo HM, Vandertop WP, Gerritsen WR: Potential of the conditionally replicative adenovirus Ad5-Delta24RGD in the treatment of malignant gliomas and its enhanced effect with radiotherapy. Cancer Res 2002, 62:5736-5742.

16. Fueyo J, Alemany R, Gomez-Manzano C, Fuller GN, Khan A, Conrad CA, Liu T], Jiang H, Lemoine MG, Suzuki K, Sawaya R, Curiel DT, Yung WK, Lang FF: Preclinical characterization of the antiglioma activity of a tropism-enhanced adenovirus targeted to the retinoblastoma pathway. I Natl Cancer Inst 2003, 95:652-660.

17. Bauerschmitz G], Kanerva A, Wang M, Herrmann I, Shaw DR, Strong TV, Desmond R, Rein DT, Dall P, Curiel DT, Hemminki A: Evaluation of a selectively oncolytic adenovirus for local and systemic treatment of cervical cancer. Int J Cancer 2004, I I I:303-309.

18. Hemminki A, Kanerva A, Kremer EJ, Bauerschmitz G], Smith BF, Liu B, Wang M, Desmond RA, Keriel A, Barnett B, Baker HJ, Siegal GP, Curiel DT: A canine conditionally replicating adenovirus for evaluating oncolytic virotherapy in a syngeneic animal model. Mol Ther 2003, 7:163-173.

19. Blackwell JL, Li H, Gomez-Navarro J, Dmitriev I, Krasnykh V, Richter CA, Shaw DR, Alvarez RD, Curiel DT, Strong TV: Using a tropismmodified adenoviral vector to circumvent inhibitory factors in ascites fluid. Hum Gene Ther 2000, I I:1657-1669.

20. Hemminki A, Belousova N, Zinn KR, Liu B, Wang M, Chaudhuri TR, Rogers BE, Buchsbaum DJ, Siegal GP, Barnes MN, Gomez-Navarro J, Curiel DT, Alvarez RD: An adenovirus with enhanced infectivity mediates molecular chemotherapy of ovarian cancer cells and allows imaging of gene expression. Mol Ther 200I, 4:223-231.
21. Jia SF, Worth LL, Turan M, Duan Xp XP, Kleinerman ES: Eradication of osteosarcoma lung metastasis using intranasal gemcitabine. Anticancer Drugs 2002, 13:155-161.

22. Li X, Jung C, Liu YH, Bae KH, Zhang YP, Zhang HJ, Vanderputten D, Jeng MH, Gardner TA, Kao C: Anti-tumor efficacy of a transcriptional replication-competent adenovirus, Ad-OC-Ela, for osteosarcoma pulmonary metastasis. J Gene Med 2006, 8:679-689.

23. Folkman J: Seminars in Medicine of the Beth Israel Hospital, Boston. Clinical applications of research on angiogenesis. $\mathrm{N}$ Engl J Med 1995, 333:1757-1763.

24. Grootenboers MJ, Heeren J, van Putte BP, Hendriks JM, van Boven WJ, Van Schil PE, Schramel FM: Isolated lung perfusion for pulmonary metastases, a review and work in progress. Perfusion 2006, 2 I:267-276.

25. developmental and therapeutics program $\mathrm{NCI} / \mathrm{NIH}$; rapid access to intervention development [http://dtpncinihgov/ branches/brb/bdp/bdpraidhtml\#bdp project 445].
Publish with Bio Med Central and every scientist can read your work free of charge

"BioMed Central will be the most significant development for disseminating the results of biomedical research in our lifetime."

Sir Paul Nurse, Cancer Research UK

Your research papers will be:

- available free of charge to the entire biomedical community

- peer reviewed and published immediately upon acceptance

- cited in PubMed and archived on PubMed Central

- yours - you keep the copyright

Submit your manuscript here:

http://www.biomedcentral.com/info/publishing_adv.asp
BioMedcentral 